\title{
Mother-Child Interactions in a Stressful Situation by Mother's Emotional Regulation Level
}

\author{
Eun Young Nahm, So Eun Park \\ Department of Child Studies, Seoul Women's University, Seoul, Korea \\ 스트레스 상황에서 어머니의 정서조절 수준에 따른 어머니-자녀 간 \\ 상호작용 분석 \\ 남은영, 박소은 \\ 서울여자대학교 아동학과 아동심리학전공
}

Objective: This study analyzed mother-child interactions in a stressful situation each second by mother's emotional regulation level.

Methods: The study was conducted with 16 mothers and their 5-year-old children playing a teaching task for $15 \mathrm{~min}$. During the interactions, the participants were videotaped and examined. Furthermore, qualitative analysis was used for analyzing mother-child interactions in detail by creating a situation that maximizes the stress and frustration of the mother and child.

Results: The results showed that maternal humor and affection were significantly related to child positive emotion and that maternal coaching closely correlated with the child pride, pleasure, and whining. Additionally, maternal intrusive behavior showed a positive correlation with child anger. Lastly, mothers with higher levels of emotional regulation more often expressed affection to their children. They were more actively involved in the tasks and used fewer positive or negative directive expressions. Therefore, children of this group expressed more positive emotions.

Conclusion: These findings suggests that programs improving parental emotional reaction and emotion regulation should be developed.

Keywords: mother-child interaction, maternal emotion regulation, observational behavioral coding

\section{서론}

현대 사회의 부모는 급격하게 변화하는 시대 속에서 다양한 외부적 스트레스 요인에 노출이 증가하고 있다. 따라서 일상 의 스트레스 상황에서 자신의 정서를 효과적으로 다루고 자녀 와 정서적으로 건강한 상호작용을 하는 것이 건강한 부모-자 녀 관계에 있어 중요하다. 특히, 부모와 자녀의 상호작용 가운

Corresponding Author: Eun Young Nahm, Department of Child Studies, Seoul Women's University, 621, Hwarang-ro, Nowon-gu, Seoul, Republic of Korea.

E-mail: nahmey@swu.ac.kr
데 이뤄지는 정서적 교류는 아동의 발달에 매우 중요한 영향 을 미친다(Blair \& Raver, 2012; Gross \& Thompson, 2007).

Eisenberg, Cumberland 그리고 Spinard (1998)는 이러한 부모 자녀 상호작용의 발달적 특성을 설명하기 위해 정서사회화 모 델을 제안하였다. 즉, 부모가 아동의 정서에 대해 제공하는 직 · 간접적인 피드백, 가정 내 정서적 분위기, 모델링을 통한 사 회화 행동이 자녀의 정서발달에 중요한 역할을 함을 강조하

CCThe Korean Association of Child Studies

This is an Open Access article distributed under the terms of the Creative Commons Attribution Non-Commercial License (http:// creativecommons.org/licenses/by-nc/4.0) which permits unrestricted noncommercial use, distribution, and reproduction in any medium, provided the original work is properly cited. 
였다(Denham, Bassett, \& Wyatt, 2007). 더불어 부모 자신이 경 험한 정서에 대한 인식과 수용 및 조절 역시 자녀의 정서적 반 응으로 구체화되어 자녀의 정서사회화 발달에 핵심적 요인으 로 나타났다(Gottman, Katz, \& Hooven, 1997). 실제로, 부모-자 녀 상호작용에서 자녀의 정서반응에 대한 부모의 긍정적 정 서표현성은 아동의 정서조절, 사회적 유능성, 적은 문제행동 과 관련이 있었다(Meyer, Raikes, Virmani, Waters, \& Thompson, 2014; Morris, Silk, Steinberg, Myers, \& Robinson, 2007). 반면, 부모의 비지지적인 반응은 아동의 정서적 반응성에 부정적 영 향을 미치며, 아동의 잦은 감정 변화와 충동성 및 전형적인 외 현화 문제들을 예측하는 것으로 나타났다(Meyer et al., 2014;

Pasalich, Waschbusch, Dadds, \& Hawes, 2014).

한편 부모의 정서반응은 부모의 스트레스에 영향을 받는 다. 부모의 높은 스트레스는 처벌적이고 강압적 양육행동 등 부정적 양육행동을 유발한다고 보고된다(Anthony et al., 2005). 그 외에도, 자녀와의 사회적 상호작용에서 적절한 자 극을 제공하지 못하고 불안적 애착으로 연결되며(Jarvis \& Creasey, 1991), 결국 이후의 아동 행동문제 및 공격성에 영향 을 미친다(Lee, 2008). 이처럼 스트레스는 부모의 양육행동에 영향을 미칠 뿐 아니라, 자녀의 실제 상호작용 맥락의 질과 관 련이 있어, 스트레스 상황을 적절하게 대처하고 다루는 회복 능력 역시 부모-자녀 상호작용에 중요한 요소로 작용함을 예 측해볼 수 있다. Skinner와 Wellborn (1994)에 따르면, 스트레스 상황에서 부정적 정서를 효과적으로 조절하는 부모는 스스로 스트레스를 잘 통제하고 상황에 성공적으로 대처하며 긍정적 정서표현을 많이 보인다고 보고하였다. 그리고 이런 부모의 자녀 또한 실망스러운 상황에서도 부정적인 정서를 보이지 않 고 효과적으로 정서조절을 한다고 나타났다(Garner \& Power, 1996). 반면, 어머니가 스트레스에 충동적 정서조절 방식을 보 일수록, 아동은 감정 발산적이고 공격적이거나 회피적 정서조 절 방법을 보였다(Lim \& Park, 2002). 더불어 어머니의 부정적 인 정서적 태도는 자녀의 심리적 갈등 및 부정적 정서상태를 강화시킬 뿐 아니라, 내재화, 외현화 문제 및 임상적 장애 등에 영향을 미치는 것으로 나타났다(Romens \& Pollak, 2012). 궁극 적으로 어머니가 스트레스 상황에서도 자신의 정서를 잘 조절 하여 자녀에게 따뜻하고 반응적인 태도를 보일수록 아동의 안 정적 애착, 높은 자존감 및 긍정적 정서발달과 관련이 있다고 볼 수 있다.

그러나 현재까지 국내에서 어머니와 자녀 간 상호작용을 관찰하여 정서적 반응을 직접적으로 살펴본 연구는 제한적일 뿐 아니라 주로 아동의 부정적 정서에 대한 어머니의 정서적
반응에 초점을 두거나 설문지 연구를 통한 어머니의 자기보고 에 의존하고 있는 경우가 대부분이다. 이에 본 연구는 스트레 스 상황에서 어머니의 정서조절 수준과 함께 어머니-자녀 상 호작용에서 드러난 반응들 간 관계를 밝히고자 하였다. 그리 고 실제 상호작용과 유사한 어머니와 자녀의 반응을 도출하고 자 약간의 긴장감과 자연스럽게 스트레스가 유발되는 게임 상 황을 설정하여 관찰연구를 실시하였다. 녹화된 자료는 어머니 의 정서반응 및 참여행동과 아동의 정서반응으로 양적자료로 변환하여 반응의 지속시간을 실시간 초단위로 분석하였고, 그 관계를 살펴봄으로서 측정의 객관적 분석을 도모하고자 하였 다. 더불어 어머니-자녀 상호작용 도중, 타인의 개입으로 의도 치 않게 실험을 방해받는 경험을 제공하여 스트레스와 좌절감 이 가중되는 상황의 어머니 정서조절 수준을 살펴보고자 하였 다. 외부 방해로 블록이 무너지는 상황은 어머니와 자녀 모두 에게 스트레스가 상승될 수 있는 상황이나, 본 연구에서는 어 머니의 정서조절 방식이 모자녀 상호작용에 더 중요한 영향을 줄 것이라는 데 무게를 두고 있다. 또한 고조된 스트레스 상황 에서 보인 어머니의 정서조절 방식이 전반적 상호작용 가운데 드러날 것이라고 가정하에 탑이 무너지기 전 상황을 포함한 전체 상호작용을 분석하였다.

어머니의 정서조절 수준은 단순히 상호작용 내 보이는 반 응의 양이나 빈도만으로 측정하기가 어렵기 때문에 스트레 스 상황에서 보여주는 행동적 특성을 전사하여 질적인 분석 을 하였다. 정서조절에 관한 대부분의 선행연구들에 따르면, 정서조절에 대한 정의로 자기조절의 측면을 강조하며(Gross, 1998), 부정적 정서경험을 감소시키기 위한 노력에 초점을 두 고 있다(Baumeister, Heartherton, \& Tice, 1994). 또한 정서조 절의 방식으로는 크게 부정적 정서에 대한 능동적, 적극적 대 처 방식과 회피적, 주의분산적 대처방식으로 구분하고 있다 (Parkinson, Totterdell, Briner, \& Reynolds, 1996). 그러나 이러한 분류는 다양한 정서조절 방식을 포괄하기에 충분하지 않아, 본 연구에는 어머니의 행동과 말 뿐 아니라 목소리 톤 얼굴표 정 외 여러 비언어적 단서를 포함하는 Kahen (1995)이 개발하 고 Nahm (2006)이 개정 및 번안한 KACS (Kahen Affect Coding System)의 하위요인 및 Gurovich (1999)의 정서조절척도를 수 정 및 번안한 Lim과 Park (2002)의 정서조절 유형 구분 기준 (예: 감정압도형, 억제형, 표현형 등)을 근거로 개념을 정리하 였다.

특별히 학령 전 시기는 다른 발달 시기에 비해 상대적으 로 가정환경적 맥락에 많은 영향을 받는 시기이며 $(\operatorname{Kim} \& \mathrm{Yu}$, 2011), 어머니가 가장 밀접한 상호작용 대상으로, 어머니의 정 
서사회화 행동은 아동에게 가장 큰 핵심이 된다(Eisenberg et al., 1998). 특히 만 5세는 여전히 부모의 영향을 크게 받으며, 부모와의 상호작용을 통해 정서에 대한 표상과 사회화를 형성 할 뿐 아니라(Meyer et al., 2014), 이를 통해 자신만의 정서반응 과 책략들을 갖게 되는 시기이다(Denham \& Kochanoff, 2002). 또한 본 연구의 실험과제를 잘 이해하고 몰입할 수 있는 연령 에 해당된다. 따라서 만 5 세 아동과 어머니 간 상호작용에서 나타난 어머니의 정서반응 및 참여행동과 아동의 정서반응 간 관계의 탐색은 이 시기의 어머니-자녀 간 정서적 상호작용에 대한 이해 폭을 넓혀줄 것으로 보인다. 이에 따른 본 연구의 연 구문제는 다음과 같다.

\section{연구문제 1}

어머니-자녀 상호작용에 나타난 어머니 정서반응 및 참여행 동과 아동의 정서반응 간의 관계는 어떠한가?

\section{연구문제 2}

스트레스 상황에서 어머니 정서조절 수준에 따른 집단 간 특 성은 어떠한가?

\section{연구문제 3}

스트레스 상황에서 어머니 정서조절 수준에 따라 어머니 정 서반응 및 참여행동과 아동의 정서반응에는 차이가 있는가?

\section{연구방법}

\section{연구대상}

본 실험은 서울시에 거주하는 양부모 가정의 만 5세 자녀와 그 들의 어머니 16쌍을 대상으로 하였다. 'EBS 다큐프라임'프로 그램 제작을 위해 방송사 홈페이지에 게시한 연구참여자 모집 공고를 보고 전화연락을 한 부모들에게 실험 절차를 설명하였 고, 비디오 촬영을 포함한 실험참여에 대해 사전 동의를 먼저 구하였다. 자발적 의사를 밝힌 18 명 중 실험을 도중에 중단한 경우(2명)를 제외한 16 쌍의 자료가 분석에 사용되었다. 어머 니 평균연령은 만 38.8세 $(S D=3.35)$, 아동 평균연령은 만 5세 $(S D=0.00)$ 로, 이 중 남아가 8 명, 여아는 8 명이었다. 본 실험연 구에서는 어머니의 수입이나 교육수준과 같은 연구대상의 일 반적인 배경은 대상이 적어 통계적으로 무의미하므로 수집하 지 않았다.

\section{연구도구}

어머니 상호작용 실험에는 $\mathrm{Nahm} \mathrm{(2006)이} \mathrm{고안한} \mathrm{젠가를} \mathrm{활}$ 용한 Teaching-Task 실험을 사용하였다. 실험규칙은 다음과 같 다. 자녀가 3 개의 블록으로 구성된 총 18 개 층의 젠가 탑 사이 에서 최상단을 제외한 아래 블록들을 하나씩 꺼내 그 위로 다 시 8 층의 탑을 더 쌓는다. 제한시간은 15 분으로, 어머니는 언 어적 지시를 통해서만 자녀를 도울 수 있으며, 탑이 무너지더 라도 제한시간 내에서 원하는 만큼 다시 시작할 수 있다. 과제 에 사용된 젠가 블록게임의 규칙은 예비실험을 통해 자녀 연 령의 적합성을 고려한 것으로(Park \& Nahm, 2010), 제한된 시 간설정은 어머니와 자녀에게 자연스러운 긴장감을 줄 수 있 다. 본 실험에 참여한 아동들은 일반적으로 과제 시작과 동시 에 매우 집중적으로 과제에 임하였다. 이를 위한 장치로 실험 전, 과제 성공 시에 선물을 제공한다고 부모와 아동에게 미리 알려주었다.

상호작용 관찰은 Kahen (1995)이 개발하고 Nahm (2006)이 개정 및 번안한 Kahen 정서코딩체계(KACS)를 사용하였다. 이 를 통해 자연스러운 스트레스 상황에서 어머니가 자녀에게 정 서적으로 접근하는 반응 및 아동의 정서반응을 분석하고자 하 였다. KACS는 부모-자녀 상호작용에서의 정서반응성과 아동 의 정서발달 측정에 널리 사용되었을 뿐 아니라(Gottman \& Katz, 2002; Katz \& Gottman, 1997), 선행연구들을 통해 측정 의 유용성과 타당성이 입증된 관찰코딩체계이다(Kahen, Katz, \& Gottman, 1994; Locke \& Prinze, 2002). KACS의 하위요인은 크게 어머니의 정서코드와 참여행동코드, 아동의 정서코드로 나뉘며, 어머니 정서는 긍정정서(유머형, 애정형), 부정정서 (분노/좌절/비난, 긴장형/긴장형유머, 경멸형), 중립, 알수없음 의 7 개유형으로 구분된다. 어머니 참여행동에는 긍정적참여 (긍정적 지시형, 높은참여, 낮은참여, 코치형), 부정적 참여(비 참여형, 부정적 지시형, 강압형), 알수없음으로 구분된다. 아 동정서는 긍정정서(유머형, 애정형: 애정/열정/즐거움/부모를 향한 자부심), 부정정서(부정형: 분노/초조함/좌절/대항적인예전의 불순종형, 긴장형/긴장형유머, 슬픔/보채기형), 중립, 알수없음의 7 개 유형으로 구분된다.

구체적으로 어머니 정서의 애정형은 온화한 톤으로 자녀를 칭찬하거나 아동의 성취를 자랑스러워하는 것이 포함된다. 분 노/좌절/비난형은 목소리가 커지며 초조함이나 불쾌감을 표 현하는 것이 해당되며, 긴장형/긴장형유머는 높은 수준의 걱 정이나 불안한 감정으로 인한 행동과 초조한 목소리톤이 포함 된다. 어머니 참여행동에 있어 긍정적 지시형은 "이쪽에서 블 
록을 빼낼 수 있겠다.”와 같이 과제를 돕는 힌트를 주는 것이 해당되며, “확실히 빨라졌다!"와 같은 아동의 행동에 대한 부 모의 적극적인 참여와 반응은 높은 참여형으로 코딩된다. 코 칭형은 “두 손을 사용하지 않으려면 어떻게 해야 할까?”와 같 이 아동이 깊이 사고할 수 있게 하는 조언이 되는 질문을 의미 한다. 부정적 지시형은 ‘그만', '아니' 등의 부정적인 말로 지시 하는 것을 포함한다. 아동 정서의 경우, 애정형은 부모를 향한 미소, 성공에 자랑스러워하는 증거와 행복함 등이 포함된다. 반면 부모의 행동이나 질문에 좌절하고 분노를 표현하며, 격 앙된 얼굴단서들은 부정형 정서로 코딩한다.

관찰은 15 분간 녹화되었으며, 컴퓨터 분석 프로그램인 INTERACT 8 (Mangold, 2008)을 사용하여 상호작용을 분석 하였다. 코딩은 KACS의 하위요인 단축키를 키보드 상에 입력 시킨 다음, 녹화한 영상에서 확인된 어머니의 정서반응 및 참 여행동 그리고 아동의 정서반응을 각각 실시간 초단위로 기록 된다. 기록된 코드는 자동으로 수량화되며, 각 하위요인의 지 속시간이 산출된다. 산출된 수치가 높을수록 해당요인의 지속 시간이 길었음을 의미한다. 각 하위정서코드는 상호배타적이 며 위계는 없다. 평정의 신뢰도를 위해 본 연구자료 외 데이터 로 15주 이상의 코딩훈련을 통해 신뢰도 테스트를 거친 연구 자 외 연구원 1 인이 데이터의 $30 \%$ 를 더블 코딩하였으며, 평정 자간 신뢰도는 .81 로 나타났다. 이에 모든 자료는 연구자의 평 정결과로 산출하였다.

\section{연구절차}

\section{어머니-자녀 상호작용 실험}

본 실험은 스트레스 상황에서 이루어진 상호작용에서 나타난 어머니-자녀의 정서 및 행동을 관찰하기 위해 크게 세 가지 스 트레스 요인을 주고자 하였다. 첫째, 시간제한(15분), 둘째, 과 제완성요구, 셋째, 외부의 방해이며, 어머니의 정서수준은 외 부 방해로 인해 극대화된 스트레스 상황에서 분명하게 드러나 게 하였고, 나머지 두 가지 요인들도 어머니 아동 모두에게 실 험 전반적으로 스트레스를 유발하도록 하였다.

실험에 앞서, 연구자는 대상 아동이 없는 장소에서 어머니 에게 실험규칙을 설명하였다. 실험은 젠가가 놓인 탁자와 소 파가 배치된 독립적이고 조용한 방에서 개별적으로 진행하였 으며, 관찰을 위해 카메라를 설치하여 실험의 전 과정을 녹화 하였다. 연구자는 가중된 스트레스 하에서 보인 어머니의 정 서조절 수준에 따라 어머니와 아동이 어떠한 정서적 반응을
보이는지 살펴보기 위해 의도적으로 연구원이 실수를 가장 하여 블록을 무너뜨리는 상황을 연출하였으며, 이 외 실험도 중 어떠한 개입도 하지 않았다. 연구원의 개입은 실험 중반(약 7-8분경), 블록을 어느 정도 쌓아올린 상태에서 어머니와 아동 이 실험에 적응하여 몰입도가 높아진 시점에 하였다. 전체 실 험 내용에는 의도적인 방해 외에도 아동의 실수로 탑이 무너 진 사건 모두가 포함되어있지만, 본 연구에서는 특별히 외부 의 방해로 인한 실패경험에서 상승된 어머니의 스트레스가 어 머니-자녀 상호작용에 영향을 미칠 것이라 가정하였다. 관찰 실험 진행에는 연구자 외 여러 연구원들이 함께 참여하였다.

\section{자료처리}

어머니-자녀 상호작용에서 나타난 어머니의 정서반응 및 참 여행동과 아동의 정서반응 간의 관계를 알아보기 위해 Pearson 의 적률상관분석을 실시하였다. 다음으로, 연구원의 의도적 개입으로 스트레스가 상승된 어머니의 정서조절 수준 실험 상 황의 정서반응 및 대화내용을 모두 전사하여, Yin (2003)이 제 시한 사례연구방법을 통해 질적으로 분석하였다. 이는 두 개 혹은 그 이상의 사례를 연구할 경우를 위해 고안된 기법으로 범주화 작업을 거쳐 일반화를 이끌어내는 특징을 갖는다(Yin, 2003).

분석한 자료는 연구의 신뢰도와 타당성을 얻기 위해, 연구 원 간 최종확인(member checking)을 수행함으로써 검증 작업 을 거쳤다. 이 결과를 바탕으로 어머니 정서조절 수준을 세 집 단으로 구분하여 빈도분석을 실시하였고, 본 연구의 경우, 각 집단의 표본의 수가 적어 분산의 동질성 및 정규분포를 가정 할 수 없으므로, Kruskal-Wallis비모수검정 및 Mann-Whitney U 검정을 통해 집단 간 유의한 차이를 분석하였다. 이러한 양적 및 질적분석을 활용한 통합연구방법은 연구목적을 보다 타당 하고 정확하게 달성하는데 중점을 두어, 보다 나은 이해를 창 출할 수 있는 장점을 갖는다(Creswell, Hanson, Clark Plano, \& Morales, 2007).

\section{연구결과}

\section{어머니의 정서반응 및 참여행동과 아동의 정서반응 간의 관계}

상호작용에서 관찰된 어머니 정서반응 및 참여행동과 아동 정 
서반응의 지속시간 간 상관분석결과는 다음과 같다(Table 1). 어머니 정서반응과 아동 정서반응 간 상관관계 분석 결과, 어 머니 유머는 아동의 유머와 $(r=.93, p<.01)$, 어머니 애정은 아 동의 애정과 상관을 보였다 $(r=.65, p<.01)$. 어머니 참여행동 과 아동의 정서반응관계에서 어머니의 높은 수준 참여와 아동 의 애정이 $(r=.79, p<.01)$, 어머니 코치형 질문과 아동의 애정 $(r=.63, p<.01)$ 및 슬픔/보채기 $(r=.55, p<.05)$ 와 관련이 있었 다. 반면 어머니의 강압적 행동은 아동 부정적 정서와 상관을 보였다 $(r=.69, p<.01)$.

다음으로 어머니 정서반응과 참여행동 관계에서 어머니의 애정은 높은 수준의 참여행동 $(r=.85, p<.01)$ 과 어머니의 분 노/비난 정서는 부정적 지시행동 $(r=.79, p<.01)$, 어머니의 경 멸은 비참여행동 $(r=.97, p<.01)$ 과 상관이 있는 것으로 나타 났다. 또한 중립정서는 낮은 수준 참여행동과 상관이 있었으 며, 어머니의 참여행동 간에 어머니의 긍정적 지시행동이 많 을수록 부정적 지시 또한 유의하게 많이 나타났다 $(r=.50, p<$ $.05)$. 그리고 비참여 행동이 많을수록 부정적 지시를 많이 사 용하였다 $(r=.52, p<.05)$.

\section{스트레스 상황에서 어머니 정서조절 수준에 따른 집단 간 특성}

어머니-자녀 상호작용 실험 도중 연구원의 의도적 개입으로 실험을 방해하는 상황 연출을 통해, 급상승된 스트레스 상황 에서 어머니의 정서조절 반응에 따른 집단 간 특성을 질적으 로 분석하였다. 각 집단의 반응 특성은 다음과 같다.

\section{어머니 정서조절 수준 상(上) 집단}

\section{(Id: $1,5,6,13,16$ )}

어머니 정서조절 수준 상 집단은 자신의 정서 및 자녀의 정서 를 적절하게 다루는 집단이다. 이 집단의 어머니들은 상승된 자신의 부정적 정서에 압도되지 않고 충동적이지 않았다. 이 들은 빠른 시간 내에 진정시킨 후, 자녀의 정서를 인식하고, 이 를공감해주고 격려해주며 게임을 재개할 수 있도록 이끄는 특 성을 보였다.

실제로 이 집단의 어머니는 실험 전반에 자녀와의 상호작 용에 적극적으로 참여하고 자녀의 시도에 적극적으로 칭찬을 해주며 자녀의 성취를 자랑스러워하는 모습을 보였고, 미소 짓거나 애정 어린 목소리 톤을 많이 보였다. 아동 또한 자신의 성취에 자부심을 드러내고 즐겁게 게임에 임하며, 다음 사례
와 같이 어머니에게 다정한 태도로 상호작용을 시도하는 것으 로 나타났다.

사례 1:

(연구원 등장하고, 쓰러지는 젠가)

어머니: (자녀를 향해 당황하며 혀를 내밀고 긴장형 웃음 을 보임) 어떡해... 시간 있어 다시 쌓아보자(아이의 얼굴 을 바라보며 아이의 의사를 확인한다) (블록 다시 쌓는 아이와 엄마)

어머니: (침착하게 자녀의 얼굴을 바라보며) 다시 해보 자, 할 수 있어!

자녀: (속상한 목소리로) 몇 분이나 남았어?

어머니: (밝은 목소리 톤으로 아이를 격려하며) 10 분이 나 남았어(실제 실험 종료 5분 전), 아까 그 시간에 두 배 가 남았어. 그러니까 다시 할 수 있어, (연구진에게) 이렇 게 몇 층으로 쌓은 다음에 해야 되죠?

자녀: (흥미를 보이며 자신감 있는 목소리로) 나 편하게 할 수 있는 방법 안다!

어머니: 편하게 할 수 있는 방법? 어떻게 하면 되지?

(편하게 쌓을 수 있는 방법에 대해 의논하며 블록을 다 시 쌓는다)

(ID 13, 연구원 등장시점 09:33-09:48)

\section{어머니 정서조절 수준 중(中) 집단}

(Id: 3, 11, 12, 14, 16, 17)

어머니 정서조절 수준 중 집단은 어머니 자신 및 자녀의 정서 에 민감하지 못하고, 실험에만 집중하였다. 이 집단의 어머니 들은 자신의 감정을 충동적으로 표출하지는 않았지만 자녀의 감정상태보다는 실험을 재개하여 과제를 성취하는 데에만 집 중하며 감정을 억제하는 특성을 보였다. 실험 전반에 있어 아 이가 스스로 게임을 수행해 나갈 수 있도록 도우며 긍정적인 언어적 지시를 많이 표현하지만 타인에 의해 발생한 스트레스 가 급격하게 상승된 부정적 상황에서 자녀의 정서에는 전혀 관심을 두지 못하였다. 무관심한 어머니의 정서표현에 자녀들 은 자신의 정서를 있는 그대로 표현할 기회를 잃고, 감정을 누 르거나 전환하여 다시 블록쌓기에 임하는 모습을 보였다.

사례 2:

(연구원 등장하고 쓰러지는 젠가)

어머니: (쓰러지는 블록을 잡으며 높은 긴장정서를 드러 


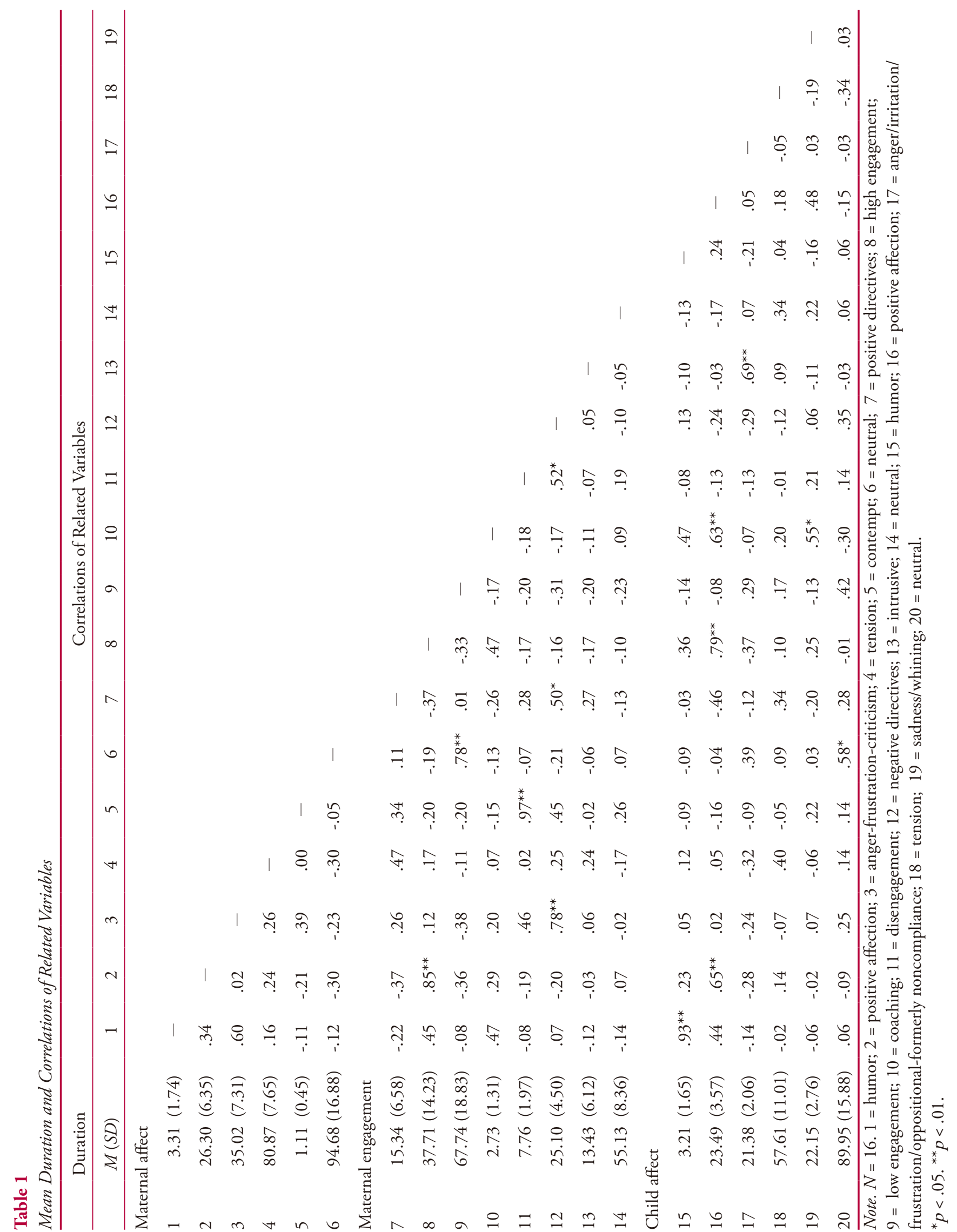


냄) 조심 조심 오오.

(허탈한 듯 웃으며) 쓰러졌어.

어머니: (한숨을 내쉬며 상승된 부정적 정서를 가다듬고 퉁명스럽게) 정빈아 다시 빨리 하자.

자녀: (자녀 역시 좌절감에 시무룩한 표정을 지으며, 허 탈해하지만 곧 엄마와 함께 무표정으로 블록을 쌓는다)

(ID 11, 연구원 등장시점 08:18-08:31)

\section{어머니 정서조절 수준 하(下) 집단}

(Id: $2,4,8,9,10)$

어머니 정서조절 수준 하 집단은 어머니 자신의 정서 조절을 어려워하며, 자녀에게 해결되지 않은 정서를 그대로 드러내었 다. 이 집단의 어머니들은 스트레스가 급격히 상승된 상황에 서 자신의 상승된 부정적 정서를 통제하지 못하고 감정에 강 하게 압도되었으며, 충동적으로 이를 강하게 그대로 표출시킬 뿐 아니라 자녀의 놀라거나 속상한 감정 및 행동에는 관심을 갖지 못하고 게임 성취에만 급급한 나머지 아동을 재촉하고 강압적으로 이끄는 모습을 보였다.

혹은 자신의 정서를 조절하지 못함으로 연구원의 사과에 도 무표정으로 일관하고, 그 사이 아동은 이러한 엄마와 연구 원의 눈치를살피며 말없이 게임을 재개하는 것이 관찰되었다. 정서조절 실험 외 실험 전반에서도 하 집단 어머니들은 직접 적인 행동이나 힌트 등의 지시를 통해 아동에게 도움이 될 수 있는 정보를 자주 제공하는 것으로 나타났다.

\section{사례 3:}

(연구원 등장하고 쓰러지는 젠가)

어머니: (연구원에게 황당하다는 듯한 언짢은 시선을 보냄) 자녀: (엄마를 바라보며) 깜짝 놀랐어. 깜짝 놀랐어..

어머니: (엄마를 보는 아이를 보지 못하고, 한숨을 쉬며 명 령조로) 어휴..주워! 떨어졌어, (연구진에게) 다시 할게요. (아 동에게) 거기도 떨어졌어?

자녀: (테이블 밑에 떨어진 블록을 보며) 이건 또 뭐지? 어머니: (성가신 듯 짜증 섞인 말투로) 아니야. 거기다 놔. 자녀: (다시 한번 자신의 정서를 표현하며) 깜짝 놀랐어. 휴! 어머니: (아동의 반응에는 관심이 없는 듯 서둘러 블록 쌓기를 지시하며) 올려, 올려. (이 때 아동이 탁자에 기대 어 탁자가 밀리자 화를 내며) 탁자 이거 많이 기대서, 흔 들려서 이게 쓰러진 거 아니야!

자녀: (시무룩하게) 깜짝 놀랬어 휴..
어머니: 이번에는 몇 개를 쌓았는지 봐야겠어, 점점 나아 지는지 (화내며) 이거봐 밀지 말라니까? 자꾸 쓰러져! 이 거 중심을 잡아서 올려야 올릴 수 있어 알았지! (엄한 목 소리로) 자 이제 다시 할 거야 한손으로만 사용 하는 거 잊지 마. 중심 잘 잡아서, 알았지? 탁자 너무 많이 흔들면 쓰러져 몇 개까지 하는지 볼거야, 알았지 이제 자 하자!

(ID 9, 연구원 등장시점 10:38-12:43)

\section{스트레스 상황에서 어머니의 정서조절 수준에 따른 어머니 정서반응 및 참여행동과 아동의 정서반응의 차이검증}

다음으로 스트레스 상황에서 어머니의 정서조절 수준에 따른 세 집단의 빈도분석 결과, 정서조절 상 집단 5명(31.3\%), 정서 조절 중 집단 6명 $37.5 \%)$, 정서조절 하 집단 5명(31.3\%)으로 분류된다. 이에 따른 어머니의 정서반응 및 참여행동과 아동 정서반응의 차이가 있는지 살펴본 결과는 Table 2 와 같다. 어 머니의 정서조절 수준에 따라 어머니의 정서표현 중 애정표현 에서 차이가 있었다 $\left(\chi^{2}=2.05, d f=2, p<.05\right)$. 집단 간 직접적 검증을 위해, 두 집단씩 Mann-Whitney U검정을 실시한 결과, 정서조절 수준 상 집단이 하 집단에 비해 애정표현을 많이 보 이는 것으로 나타났다 $(\mathrm{U}=2.50, p<.05)$. 이는 자녀를 향해 미 소, 애정 어린 목소리 톤으로 자녀를 격려하는 등 긍정적 정서 를 의미한다. 다음으로 어머니 참여행동에 있어, '하지마, 그 만, 기다려'등 부정적 말로 시작하는 부정적 지시 행동이 어머 니 정서조절 수준에 따라 유의미한 차이가 있는 것으로 나타 났다 $\left(\chi^{2}=4.08, d f=2, p<.05\right)$. 이는 정서조절 하 집단이 중 집 단에 비해 더 많은 부정적 지시 행동을 보이는 것으로 밝혀졌 다 $(\mathrm{U}=6.50, p<.05)$. 이로서 자녀를 향한 어머니의 부정적 지 시행동은 집단 간 유의한 차이가 있음을 발견하였다. 마지막 으로 아동의 정서 중 애정형에서 집단 간 차이를 보였으며 $\left(\chi^{2}=\right.$ $2.81, d f=-2, p<.05)$, 정서조절 상 집단의 아동이 하 집단의 아 동에 비해 애정형 정서를 많이 보이는 것으로 나타났다 $(\mathrm{U}=$ $2.00, p<.05)$. 이는 어머니를 향한 열정, 자부심, 긍정적 정서 적 반응에 있어 집단 간 차이가 있음을 보여준다.

\section{논의 및 결론}

본 연구는 젠가를 활용한 15 분간의 teaching-task실험을 통해, 스트레스가 유발된 긴장 상황 속에서 어머니와 자녀가 어떻게 
Table 2

Differences in Emotional Response According to Mothers' Emotional Regulation Level

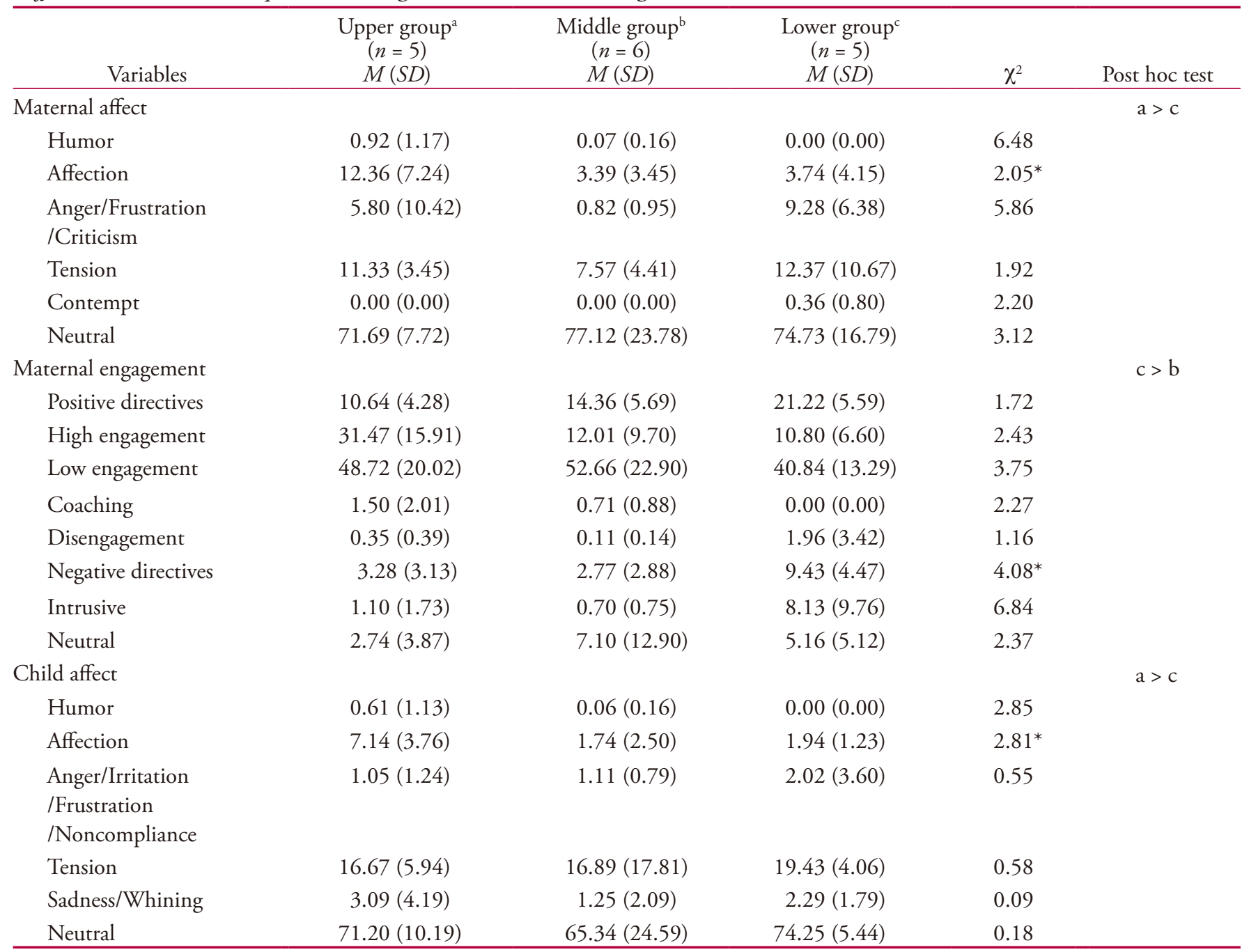

Note. $N=16$.

${ }^{*} p<.05$.

상호작용 하는지를 살펴보았다. 구체적으로 상호작용 내에서 어머니의 정서반응 및 참여행동과 아동의 정서반응을 측정하 였으며, 컴퓨터를 활용한 초 단위 분석을 실시하였다. 특히 본 연구에서는 게임 도중 연구원이 등장하여 블록을 실수로 무너 뜨리는 상황을 추가하여, 어머니와 아동의 스트레스와 좌절감 을 급격히 상승시킨 후, 이 시점에서 보인 어머니의 정서조절 반응을 살펴보았다. 이는 녹화 자료를 전사한 내용을 토대로 질적으로 분석하였으며, 어머니의 정서조절 수준에 따라 세 집단으로 구분하였다. 아울러 어머니 정서조절 수준에 따른 어머니와 자녀의 정서적반응의 집단 간 차이를 분석하였다.

첫째, 어머니와 자녀의 상호작용에서 어머니의 정서반응 및 참여행동과 아동의 정서반응 간 관계를 살펴본 결과, 어머
니가 자녀와 공유할 수 있는 유머러스한 표현을 자주 사용할 수록 자녀 역시 유머를 자주 사용하였고, 자녀에게 온정적인 긍정적 반응을 많이 보이고 적극적으로 과제수행에 개입하여 참여할수록 자녀 또한 자신의 과제수행을 자랑스러워하고 즐 거워하는 것으로 나타났다. 이러한 연구결과는 Landry, Smith, MillerLoncar 그리고 Swank (1998)의 어머니의 정서적 조율 모 형을 통해 제안한 바와 같이, 어머니의 자녀를 향한 따뜻한 민 감성과 주의를 기울이는 언어적, 비언어적 반응이 자녀와의 상호작용에서 핵심적 역할을 한다는 연구결과를 지지한다. 그리고 Denham (1998)이 아동의 정서에 긍정적으로 표현하 는 어머니의 아동은 긍정적 정서표현을 많이 한다고 보고한 연구결과와 일치한다. 또한 부모의 유머가 아동의 긍정적 정 
서성과 관련이 있음을 밝힌 연구와 맥을 같이한다(Hwang \& $\mathrm{Oh}, 2014)$. 특히 온정적이며 지지적인 부모의 자녀는 스트레 스 상황을 보다 잘 통제하고 성공적으로 대처한다는 Skinner 와 Wellborn (1994)의 연구 및 어머니가 자녀와 상호작용 시 보 이는 온정성이 자녀의 긍정적 사회 정서적 적응에 영향을 미 치는 중요한 요인임을 밝힌 연구(Zhou et al., 2002)와도 일치 하는 결과이다.

그리고 어머니가 자녀에게 조언이 될 수 있는 질문을 던지 거나 자녀 스스로 문제해결을 할 수 있도록 이끌수록 자녀는 과제수행에 대한 열정과 자부심을 보이는 것으로 나타났다. 이 는 부모의 관심어린 질문이 자녀가 과제 수행에 더 흥미와 열 정을 보이도록 이끌었고, 스스로의 수행 결과에 자부심을 느 끼도록 도와주었다고 볼 수 있다. 그러나 흥미롭게도 어머니의 코칭 질문은 과제 수행 시, 자녀의 슬픔 및 칭얼거림과도 관련 이 있었다. 슬픔 및 칭얼거림 코드는 입을 삐죽거리거나 부루 퉁하게 보이며 보채는 목소리 톤을 사용하는 단서들을 포함한 다. 아이는 부정적 정서를 경험할 때 부모를 가장 필요로 할 뿐 아니라(Gottman \& Nahm, 2007), 대상 아동의 연령이 어리기 때문에 아이의 칭얼거림은 어머니가 자녀에게 직접적인 도움 없이 스스로 과제를 해결할 수 있도록 돕는 상황에서 어머니에 게 도움을 요청하는 하나의 정서적 반응으로 볼 수 있다.

반면, 아동의 팔을 잡는 등 아동이 원하지 않는 신체적 접촉 으로 아동에게 방향을 제시하거나 아동의 요청 없이 어머니가 직접 블록을 움직이는 등 강압적 행동을 보이는 아동은 부모 의 행동이나 말에 입술을 굳게 다무는 것과 같은 억눌린 분노 를 보인 것으로 나타났다. 또한 원하는 방향으로 과제가 잘 풀 리지 않을 때에 보다 얼굴을 찌푸리고 좌절을 표현하는 모습 을 보였다. 이는 어머니의 답답하고 불안한 부정적인 생각과 정서가 자녀에게 전달됨으로서 자녀 역시 강한 부정적 정서 를 경험한 것으로, 아동에게 높은 수준의 부정적 정서나 강압 적 태도를 보이는 부모의 아동은 부모의 지시를 따르도록 하 는 동기가 사라지게 되며, 낮은 정서조절 전략을 보인다는 연 구결과와 일치하는 결과이다(McDowell, Kim, O’Neil, \& Parke, 2002). 어머니가 강압적으로 접근할수록 자녀는 정서적으로 불안정해지며 좌절스러운 상황을 잘 견디지 못해 과제수행에 서 부정적 정서를 많이 드러내게 되고 과제수행상황을 힘겹게 경험하고 있음을 보여주고 있다.

이러한 연구결과들은 어머니와 자녀의 상호작용 내에서 나 타난 어머니의 사회화 행동과 정서적 반응이 아동의 정서적 반응과의 관련성을 입증해주며, 아동의 긍정적 정서발달을 증 진시키기 위해 어머니의 바람직한 정서사회화를 위한 중재적
노력이 필요함을 시사한다.

둘째, 급격히 상승된 어머니와 자녀의 스트레스 상황에서 어머니의 정서조절 수준의 특성을 살펴본 결과, 정서를 잘 조 절하는 어머니들은 부정적 정서에 압도되지 않고 충동적이지 않았으며, 자신의 정서를 적절하게 다루고 동시에 자녀의 정 서에도 민감하게 반응하였다. 반면 정서조절 수준이 낮은 어 머니들은 자신의 정서를 조절하지 못하고 자녀의 부정적 정서 역시 다루어주지 못했을 뿐 아니라 충동적으로 자녀에게 자신 의 해결되지 않은 정서를 그대로 드러냈다. 일부 어머니들은 자신의 부정적 정서를 자녀에게 표출하지는 않았으나 자녀의 정서에 민감하지 못하거나 전혀 관심을 보이지 못하고 이를 억제하며 실험에만 집중하는 경우도 있었다.

이처럼 정서를 잘 조절하는 어머니들은 부정적인 정서를 조절하기 위한 가장 효과적인 정서조절 방식 중 하나인 능동 적 정서조절의 특성을 보였다(Shin, Lee, \& Lee, 2005). 이는 상 황 혹은 문제 및 자신의 느낌을 보다 명확히 이해하고자 노 력하며, 문제해결을 위한 계획을 세우고, 구체적인 일을 한 다고 밝힌 연구결과를 반영하는 것이라 볼 수 있다(Thayer, Newman, \& McClain, 1994). 즉, 이들은 직면한 부정적 정서 에 압도되지 않고, 자신의 정서를 인식하고 수용하며 조절하 는 차원에서 한 단계 더 나아가 자녀의 정서를 다루어주는 등 정서적 신호에 상당히 유연함을 보여주고 있었다(Gottman et al., 1997). 이러한 자신의 정서 뿐 아니라 자녀의 정서에 대해 민감하고 수용적인 신념을 갖는 어머니들은 평소 정서를 경험 하는 상황을 더 잘 이해하고 표현하고 조절하는데 어려움을 겪지 않을 뿐 아니라 회복에도 능숙하다고 보고된다(Katz \& Windecker-Nelson, 2004). 하지만 정서조절에 능숙하지 못한 어머니들의 경우, 자신의 정서를 표현하지 못하고 자신의 정 서를 부정적으로 이를 표출하는 것을 확인할 수 있었다. 이는 한국사회의 사회문화적 특성 상 부정적 정서를 솔직히 표현하 기보다 우회적으로 혹은 이를 억제하는 것을 선호하는 경향성 이 반영된 결과일 수도 있지만 긴장과 스트레스가 유발되는 상황 안에서 부정적 정서를 어떻게 다루어야 하는지, 어떻게 이를 표현하고 행동하는 것이 적절한지에 대한 이해가 부족한 것으로 볼 수 있겠다.

셋째, 어머니의 자녀를 향한 애정형 정서와 아동의 정서반 응 중 애정형이 어머니 정서조절 수준에 따른 차이를 보였다. 이는 어머니가 자신 및 아동의 정서에 대해 인식하고 조절하 며 아동의 정서표현을 격려하는 경우, 자녀는 부정적 정서를 잘 다룰 뿐 아니라 마음을 힘들게 하는 사건에서 빠르게 회복 하며, 인지적, 사회적, 신체적으로 그렇지 않은 자녀에 비해 뛰 
어나고 무엇보다 부모-자녀 관계의 초석이 되는 정서적 친밀 감을 형성하게 한다고 밝힌 연구를 지지한다(Gottman, Katz, $\&$ Hooven, 1996). 반면, 어머니 참여행동에서 부정적 지시행 동이 어머니의 정서조절 수준 집단 간 차이가 있는 것으로 나 타났다. 이는 과도하게 지시적 양육태도를 보이는 경우 자녀 의 자기조절능력을 약화시킨다고 보고한 연구결과와 유사하 다(Eisenberg et al., 1999). 또한 아동에게 무반응적이며 제한 설 정을 잘 하지 못하는 부모의 아동은 분노와 같은 부정적 정서 를 많이 표현한다고 밝힌 연구(Gottman \& Nahm, 2007)와도 같은 맥락으로 볼 수 있다.

본 연구가 갖는 의의는 다음과 같이 요약할 수 있다. 첫째, 지 금까지 학령전기 아동과 어머니의 상호작용을 다룬 연구들에 서는 대부분 실험연구가 널리 활용되지 못하였다. 이에 본 연구 는 컴퓨터를 활용한 실시간 초단위 분석 프로그램을 활용하여 상호작용을 측정하였다는 점에서 차별성을 갖으며, 어머니와 학령전기 아동의 정서적 상호작용 양상을 심도있게 살펴, 보다 실질적이고 유용한 결과들을 보고하였다는데 의의가 있다.

둘째, 본 연구는 어머니 정서조절 방식을 질적으로 분석하 여 집단 간 차이를 밝힘으로서, 양적인 측면에서 나아가 질적 인 분석을 포함하는 통합연구방법을 적용하였다는데 의미를 갖는다. 이는 양적 연구가 갖는 한계점을 보완함과 동시에, 어 머니-자녀 상호작용에서 나타난 어머니 정서조절에 대한 심 층적 분석을 가능하게 하였다. 이로서 어머니의 적응적이고 효과적인 정서조절에 대한 중요성과 실질적인 접근이 필요함 을 시사한다.

셋째, 학령전기 아동과 어머니의 친밀한 정서적인 상호작 용에 있어 어머니의 온정적이며 공유 가능한 웃음을 제공하는 능력 및 직접적인 지시나 강압적 태도 보다 자녀 스스로 문제 를 해결할 수 있도록 여지를 제공하고 조언을 하는 접근이 자 녀의 성취에 대한 자부심 및 즐거움과 같은 긍정적 정서와 관 련이 있음을 밝혔다. 아울러 어머니가 자신의 부정적 정서를 잘 다루는 경우, 자녀의 정서에도 애정적으로 반응해주며 자 녀 역시 어머니와 긍정적 정서로 상호작용하는 것을 확인하 였다. 이는 학령 전 자녀를 둔 어머니를 대상으로 어머니-자녀 간 긍정적 상호작용을 촉진하기 위한 부모교육프로그램 개발 의 기초자료로 활용될 수 있을 뿐 아니라, 교육 및 상담장면에 서 효과적인 부모-자녀 관계 정립을 돕기 위한 중요한 시사점 을 제공하고 있다. 특히 어머니 정서조절과 아동의 정서적 반 응에 대한 폭 넓은 이해를 가져왔다는데 의의가 있다.

본 연구의 제한점과 후속 연구를 위한 시사점은 다음과 같 다. 첫째, 본 연구는 학령 전기 아동과 그들의 어머니를 대상으
로 하여 정서적 상호작용을 분석하였으나, 대상 수가 적어 추 후에 더 많은 연구대상을 선정하여 유사한 결과가 나타나는 지 반복 검증할 필요가 있겠다. 둘째, 본 연구의 정서조절수준 을 구분함에 있어 어머니의 정서조절방식에 주목하여 질적분 석을 통해 접근하였다는 점은 기존 연구와 차별성을 갖는다. 그럼에도 불구하고 관찰자의 주관이 개입되었을 가능성을 배 제할 수 없음을 밝힌다. 셋째, 본 연구의 어머니 정서조절 수준 분석은 스트레스 상황에서 보이는 대처에 따라 정서조절 수준 을 구분한 것이다. 그러나 Gross (1998)에 따르면, 정서가 유발 되는 동기 혹은 인지 및 신체적 과정 등에 따라 정서마다 다른 조절 방략을 사용할 수 있음을 밝힌 바, 부정적 정서 상태나 스 트레스 상태로부터 벗어나기 위해 어떤 대처방법을 사용하는 지 혹은 효과적인지를 연구하기 위해서는 여러 부정적 정서가 갖는 특성들을 고려하여 연구하는 것이 필요하다. 추후 연구 에서는 이러한 한계점들을 보완하여 자연스럽고 다양한 상황 에서 연구를 진행하여 본 연구를 확대할 필요가 있다고 본다.

\section{Acknowledgements}

This work was supported by a research grant funded by Seoul Women's University (2016). The authors would like to thank Producer Mintae Kim and EBS Documentary staffs for their support in data collecting.

\section{Notes}

This article was presented as a poster at the 2015 Annual Conference of Korean Psychological Association.

\section{Conflict of Interest}

No potential conflict of interest relevant to this article was reported.

\section{References}

\section{In English}

Anthony, L. G., Anthony, B. J., Glanville, D. N., Naiman, D. Q., Waanders, C., \& Shaffer, S. (2005). The relationships 
between parenting stress, parenting behavior and preschoolers' social competence and behavior problems in the classroom. Infant and Child Development, 14, 133-154. doi:10.1002/icd.385

Baumeister, R. F., Heatherton, T. F., \& Tice, D. M. (1994). Losing control: How and why people fail at self-regulation. San Diego: Academic Press.

Blair, C., \& Raver, C. C. (2012). Child development in the context of adversity: Experiential canalization of brain and behavior. American Psychologist, 67(4), 309-318. doi:10.1037/a0027493

Creswell, J. W., Hanson, W. E., Clark Plano, V. L., \& Morales, A. (2007). Qualitative research designs: Selection and implementation. The Counseling Psychologist, 35(2), 236264. doi: $10.1177 / 0011000006287390$

Denham, S. A. (1998). Emotional development in young children. New York: Guilford Press.

Denham, S. A., Bassett, H. H., \& Wyatt, T. (2007). The socialization of emotional competence. In J. E. Grusec \& P. D. Hastings (Eds.), Handbook of socialization: Theory and research (pp. 614-637). New York: Guilford Press.

Denham, S., \& Kochanoff, A. T. (2002). Parental contributions to preschoolers' understanding of emotion. Marriage \& Family Review, 34(3-4), 311-343. doi:10.1300/J002v34n03_06

Eisenberg, N., Cumberland, A., \& Spinard, T. L. (1998). Parental socialization of emotion. Psychological Inquiry, 9(4), 241273. doi:10.1207/s15327965pli0904_1

Eisenberg, N., Fabes, R. A., Shepard, S. A., Guthrie, I. K., Murphy, B. C., \& Reiser, M. (1999). Parental reaction to children's negative emotions: Longitudinal relations to quality of children's social functioning. Child Development, 70, 513-534. doi:10.1111/14678624.00037

Garner, P. W., \& Power, T. G. (1996). Preschooler's emotional control in the disappointment paradigm and its relation to temperament, emotional knowledge, and family expressiveness. Child Development, 67(4), 1406-1419. doi:10.1111/j.1467-8624.1996. tb01804.x

Gottman, J. M., \& Katz, L. F. (2002). Children's emotional reactions to stressful parent-child interactions: The link between emotion regulation and vagal tone. Marriage of Family Review, 34(3-4), 265-283. doi:10.1300/J002v34n03_04

Gottman, J. M., Katz, L. F., \& Hooven, C. (1996). Parental metaemotion philosophy and the emotional life of families: Theoretical models and preliminary data. Journal of Family Psychology, 10(3), 243-268. doi:10.1037/08933200.10.3.243

Gottman, J. M., Katz, L. F., \& Hooven, C. (1997). Meta-emotion: How familes communicate emotionally. Mahwah, NJ: Lawrence Erlbaum Associates.

Gottman, J. M., \& Nahm, E. Y. (2007). The heart of parenting:
Raising an emotionally intelligent child. Seoul: Hankyung BP.

Gross, J. J. (1998). The emerging field of emotion regulation: An integrative review. Review of General Psychology, 2(3), 271299. doi:10.1037/1089-2680.2.3.271

Gross, J. J., \& Thompson, R. A. (2007). Emotion regulation: Conceptual foundations. In J. J. Gross (Ed.), Handbook of emotion regulation (pp.3-24). New York: Guilford Press.

Jarvis, P. A., \& Creasey, G. L. (1991). Parental stress, coping, and attachment in families with an 18-month-old infant. Infant Behavior and Development, 14(4), 383-395. doi:10.1016/0163-6383(91)90029-R

Kahen, V., Katz, L F. \& Gottman, J. M. (1994). Linkages between parent-child interaction and Conversations of friends. Social Development, 3(3), 238-254. doi:10.1111/j.1467-9507.1994. tb00043.x

Katz, L. F., \& Gottman, J. M. (1997). Buffering children from marital conflict and dissolution. Journal of Clinical Child Psychology, 26(2), 157-171. doi:10.1207/s15374424jccp2602_4

Katz, L. F., \& Windecker-Nelson, B. (2004). The childladolescent meta-emotion coding system. Unpublished manuscript, University of Washington.

Landry, S. H., Smith, K. E., Miller-Loncar, C. L., \& Swank, P. R. (1998). The relation of change in maternal interactive styles to the developing social competence of full-term and preterm children. Child Development, 69(1), 105-123. doi:10.1111/j.1467-8624.1998.tb06137.x

Locke, L. M., \& Prinz, R. J. (2002). Measurement of parental discipline and nurturance. Clinical Psychology Review, 22(6), 895-929. doi:10.1016/S0272-7358(02)00133-2

Mangold, P. (2008). INTERACT (version 8.7.1) [Computer software]. Arnstorf, Germany: Mangold International $\mathrm{GmbH}$.

Mcdowell, D. J., Kim, M., O’Neil, R., \& Parke, R. D. (2002). Children's emotional regulation and social competence in middle childhood: The role of maternal and paternal interactive style. Marriage \& Family Review, 34(3-4), 345364. doi:10.1300/J002v34n03_07

Meyer, S., Raikes, H. A., Virmani, E. A., Waters, S., \& Thompson, R. A. (2014). Parent emotion representations and the socialization of emotion regulation in the family. International Journal of Behavioral Development, 38(2), 164-173. doi:10.1177/0165025413519014

Morris, A. S., Silk, J. S., Steinberg, L., Myers, S. S., \& Robinson, L R. (2007). The role of the family context in the development of emotion regulation. Social Development, 16(2), 361-388. doi:10.1111/j.1467-9507.2007.00389.x

Nahm, E. Y. (2006). A cross-cultural comparison of Korean American and European American parental meta-emotion philosophy and its relationship to parent-child interaction (Doctoral 
dissertation). Retrieved from https:/www.researchgate.net/ publication/33519650

Parkinson, B., Totterdell, P., Briner, R. B., \& Reynolds, S. (1996). Changing moods: The psychology of mood and mood regulation. London: Longman.

Pasalich, D. S., Waschbusch, D. A., Dadds, M. R., \& Hawes, D. J. (2014). Emotion socialization style in parents of children with callous-unemotional traits. Child Psychiatry \& Human Development, 45(2), 229-242. doi:10.1007/s10578-0130395-5

Romens, S. E., \& Pollak, S. D. (2012). Emotion regulation predicts attention bias in maltreated children at-risk for depression. Journal of Child Psychology and Psychiatry, 53(2), 120-127. doi:10.1111/j.1469-7610.2011.02474.x

Skinner, E. A., \& Wellborn, J. G. (1994). Coping during childhood and adolescence: A motivational perspective. In D. Featherman, R. Lerner, \& M. Perlmutter (Eds.), Life-span development and behavior (Vol. 12, pp. 91-133). Hillsdale, NJ: Lawrence Erlbaum Associates.

Thayer, R. E., Newman, J. R., \& McClain, T. M. (1994). Selfregulation of mood: Strategies for changing a bad mood, raising energy, and reducing tension. Journal of Personality and Social Psychology, 67(5), 910-925. doi:10.1037/00223514.67.5.910

Yin, R. K., (2003). Case study research: Designs and method (3rd ed.). Thousand Oaks, CA: Sage Publications.

Zhou, Q., Eisenberg, N., Losoya, S. H., Fabes, R. A., Reiser, M., Guthrie, I. K., . . Shepard, S. A. (2002). The relations of parental warmth and positive expressiveness to children's empathy-related responding and social functioning: A longitudinal study. Child Development, 73(3), 893-915. doi:10.1111/1467-8624.00446

\section{In Korean}

Hwang, H. S., \& Oh, Y. K. (2014). The relationship among parents' humor style, children's emotionality, and peer competence. Family and Environment Research, 52(2), 199211. doi:10.6115/fer.2014.52.2.199

Kim, M.-J., \& Yu, Y.-O. (2011). Young children's self-regulation ability according to parents' emotional expressiveness type and their gender. The Korean Journal of Child Education, 20(1), 95-111.

Lee, J. L. (2008). Model analysis on factors affecting maternal acceptance-rejection: Mediating effects of parenting stress. Korean Journal of Child Studies, 29(2), 57-71.

Lim, H. S. \& Park, S. Y. (2002). Child's sex, temperament, mother's emotion regulation and parenting as related to child's emotion regulation. Korean Journal of Child Studies, 23(1), 37-54.

Park, S. E., \& Nahm, E. Y. (2010). The relationship of mother's emotional expressiveness, awareness, acceptance and parenting attitude: A comparison of low income and middle income families. The Korean Journal of Developmental Psychology, 23(3), 89-103. Retrieved from http://www. dbpia.co.kr/Journal/ArticleDetail/NODE06375199

Shin, J. Y., Lee, Y. A., \& Lee, K. H. (2005). The effects of life meaning and emotional regulation strategies on psychological well-being of Korean adolescents. Korean Journal Of Counseling And Psychotherapy, 17(4), 1035 1057. Retrieved from http://www.dbpia.co.kr/Journal/ ArticleDetail/NODE06369538

\section{ORCID}

Eun Young Nahm So Eun Park http://orcid.org/0000-0002-5717-7961

http://orcid.org/0000-0003-0647-2597
Received January 1, 2017

Revision received January 25, 2017

Accepted January 31, 2017 